\title{
Tarihî Türk Lehçelerinden Kazakçaya Bitki Adları Emin $\mathrm{Oba}^{*}$ \\ (Taraz)
}

\begin{abstract}
Özet: Bir dilin söz varlığını oluşturan kelime kadrosu, o dilin geçmişten getirdiği kültürel birikiminin sonucunda oluşur. Kıpçak grubu Türk lehçeleri içerisinde yer alan Kazakça, söz varlığ 1 açısından oldukça zengindir. Kazakçanın söz varlığında Türkçe kökenli sözcükler ve bu sözcüklerin türemiş şekilleri önemli bir yer tutmaktadır. Bu çalışmada Eski Türkçeden itibaren Türkçenin diğer Tarihî dönemlerinin tümünü kapsayacak şekilde sözcük hazineleri taranarak bitki adı olarak kullanılan sözcükler tespit edilmiş ve sözcüklerin bugünkü Kazakçanın söz varlığına nasıl yansıdığı araştırılmıştır. Her sözcüğün; hangi kaynakta, hangi tarihî dönemde ve hangi anlamda geçtiği ayrıntılı bir şekilde verilmiştir.
\end{abstract}

Anahtar sözcükler: Eski Türkçe, Orta Türkçe, Kazakça, bitki adları, söz varlığı.

\section{Abstract: Plant Names from Historical Turkic Dialects to Kazakh}

The vocabulary of a language is formed as a result of the cultural accumulation of that language from the past. Kazakh, which is among the Turkic dialects of the Kipchak group, is very rich in terms of vocabulary. The words from Turkish origin and derived forms of these words have a considerable place in Kazakh vocabulary. In this study, words used as plant names were determined by scanning the vocabulary of all historical periods of

\footnotetext{
* Dr., International Taraz Innovative Institute, Taraz-Kazakistan, eminoba@hotmail.com; ORCID: 0000-0002-5299-8023.
} 
Turkish starting from Old Turkic and it was investigated how these words were reflected in the vocabulary of contemporary Kazakh. For every word the details about the source the word occurs, the historical period of the source and the meaning is given.

Key Words: Old Turkic, Middle Turkic, Kazakh, plant names, vocabulary.

Giriş: Kuzey-Batı (Kıpçak) grubu Türk lehçeleri içerisinde yer alan Kazakça, konuşulduğu coğrafyanın büyüklüğü, söz varlığ hazinesi, anlatım imkânlarının zenginliği ve tarihî serüveni ile her daim araştırmacılar için ilgi odağı olmuştur.

$\mathrm{Bu}$ çalışmada Türkçenin Tarihî lehçelerinde görülen bitki adlarının Kazakçaya yansıması, yani Eski Türkçeden itibaren görülen bitki adlarının bugünkü Kazakçanın söz varlığında görülen şekilleri üzerine durulmaktadır. Her ad için, ilk olarak hangi tarihî dönemde ve tarihî eserde tespit edildiği ve şekli verilmekte, ardından adın sonraki dönemlerdeki şekilleri ve geçtiği eserler sıralanmaktadır. Böylelikle bitki adının Türkçenin tarihî seyri içerisindeki değişimleri hakkında da bilgi verilmektedir.

Çalışmada görüleceği üzere bitki adlarının birçoğu Türkçe kökenlidir. Ancak bazı alıntılar da mevcuttur. Bunların çoğu Farsçadan alıntılanmıştır. Ayrıca bazı bitki adlarının Eski Türkçeden itibaren izlenebildiği, bazılarının ise ancak DLT'den itibaren tespit edilebildiği ve sonraki dönemlerde de kullanıldığ görülmektedir. Çalışmada bir bitki adı ele alınırken o adın görüldüğü tüm dönemler ve eserlerdeki şekilleri ve anlamları da verilmiştir.

Kazakça kısmında ise, sözcüğün hangi eserde veya çalışmada geçtiği ayrıntılı bir şekilde verilmiştir. Bu kısımda sözcüklerin bazıları standart sözlüklerde ve çalışmalarda bulunamamıştır. Bundan dolayı ağızlar sözlüğüne başvurulmuştur. $\mathrm{Bu}$ kısımda görüleceği üzere, Eski Türkçeden Kazakçaya geçen bitki adları Kazakçanın fonetik yapısına göre şekillenmiştir. Hatta bazen bitki adı farklı anlamlar da kazanmıştır. 


\section{Tarihî Türk Lehçelerinden Kazakçaya Bitki Adları}

Eski Türkçeden ve Türkçenin diğer tarihi dönemlerinden Kazakçaya birçok bitki adı geçmiştir. Aşağıda tespit edilen bu bitki adları alfabetik sıraya göre verilmiştir.

alma "elma" (EDPT: 146; DTS: 36; ESTY I: 138; VEWT: 18; Tietze, 2002: 157) $\rightarrow$ Kzk. alma "elma” (Koç, 2003: 42).

Sözcük, Eski Uygurcada alımla "elma" (Röhrborn, 2015: 90), DLT'de alma, almıla "elma" şeklinde görülmektedir. Hatta DLT'de almıla kıımı “ekşi elma" şeklinde de örneklendirilmiştir (Kaçalin, 2019: 68; Hauenschild, 1994: 28). Sözcük sonraki süreçte Harezm Türkçesi eserlerinden ML'de alma "elma" (Battal, 1934: 9), Kıpçak Türkçesi eserlerinden GT ve KI' de alma “elma”, TZ'de elma "elma" (Karamanlıŏglu, 1978: 201; Atalay, 1945: 168; Caferoğlu, 1931: 3) ve Çağatay Türkçesi eserlerinden ŞHD'de alma "elma” (Karasoy, 1998: 346) şeklinde görülmektedir.

aluç (< Far. allūça) “yaban eriği; şeftali” (EDPT: 128; DTS: 40; Tietze, 2002: 85) $\rightarrow$ Kzk. alşa "yaban eriği, erik; alıç, alıç ağacı" (Koç, 2003: 43).

Sözcük DLT'de aluç “şeftali” şeklinde görülmektedir (Kaçalin, 2019: 70; Hauenschild, 1994: 28). Kıpçak Türkçesi eserlerinden BV'de aluç "alıç, yabani elma", Kİ'de alçu "bir tür yemiş" şeklinde görülmektedir (A ğar, 1986: 115; Caferoğlu, 1931: 3).

aluçın "yenilen boğumlu bir bitki" (DTS: 41) $\rightarrow$ Kzk. alşın "biçildikten sonra tekrar uzayan ot" (Koç, 2003: 43).

Sözcük sadece DLT'de aluçın "yenilen boğumlu bir bitki" şeklinde görülmektedir (Kaçalin, 2019: 70; Hauenschild, 1994: 29). 
ayduz "şifalı bir ağaç; kışın yapraklarını dökmeyen bir ağaç" (EDPT: 178; DTS: 47; Baytop, 2015: 31; Tietze, 2002: 101) $\rightarrow$ Kzk. andız "yaprakları dikenli olan bir çeşit ardıç, andız (Koç, 2003: 45).

Sözcük DLT'de $a \eta d u z$ 'andız; bu otun kökü tedavi için kullanılır; atın karın ağrısını gidermek için kullanılan bir ilaç” şeklinde görülmektedir (Kaçalin, 2019: 73; Hauenschild, 1994: 29). Sözcük Kıpçak Türkçesi eserlerinden İH'de anduz / antuz "ilaç olarak kullanılan bir ot, anduz otu" (İzbudak, 1936: 5), Çağatay Türkçesi sözlüklerinden LÇT'de anduz "ardıç türünden bir çalı" (Şeyh Süleymān Efendi, 1298: 22) şeklinde görülmektedir.

ayı "biçilen tarlada kalan kökler, anız" (EDPT: 191; DTS: 47; Tietze, 2002: 103; Eren, 1999: 13) $\rightarrow$ Kzk. ayız "buğday biçildikten sonra kalan saplar" (Iskakov I, 2011: 549).

Sözcük, Eski Uygurcada a ız "hasattan sonra kalan köklü sap, ekin anız1, saman” (Röhrborn, 2015: 203), DLT'de ayız “anız, hububat biçildikten sonra tarlada kalan köke yakın saplar" şeklinde görülmektedir (Kaçalin, 2019: 74).

arpa "arpa" (EDPT: 198; DTS: 53; Tietze, 2002: 124; Eren, 1999:

19) $\rightarrow$ Kzk. arpa "arpa" (Koç, 2003: 51).

Sözcük Eski Türkçeden itibaren Türkçenin tüm Tarihî dönemlerinde ve günümüz lehçelerinin tümünde de görülmektedir. Sözcük Eski Uygurca eserlerden Man III'te arpa "arpa" (Röhrborn, 2015: 260), DLT ve KB'de arpa “arpa" şeklinde görülmektedir (Kaçalin, 2019: 79; Hauenschild, 1994: 30; Arat, 1979: 24). Sonraki süreçte Harezm Türkçesi eserlerinden ML'de arpa "arpa" (Battal, 1934: 11), Kıpçak Türkçesi eserlerinden CC, Kİ ve TZ'de arpa "arpa" (Grønbech, 1942: 40; Caferoğlu, 1931: 5; Atalay, 1945: 141) ve Çağatay Türkçesi eserlerinden LÇT ve MK'de arpa "arpa" (Şeyh Süleymān Efendi, 1298: 8; Ölmez, 1993: 393) şeklinde görülmektedir. 
arpagan "yabani arpa" (EDPT: 200; DTS: 53; Eren, 1999: 19) $\rightarrow$ Kzk. arpaġan "arpaya benzeyen bir tür ot, çim türü” (Iskakov I, 2011: 641).

DLT'de arpag்an "arpaya benzer başağı bulunan bir tür bitki" (Kaçalin, 2019: 79; Hauenschild, 1994: 31) şeklinde görülmekle birlikte, Çağatay Türkçesi sözlüklerinden LÇT'de arparğan "arpaya benzeyen bir bitki" şeklindedir (Şeyh Süleymān Efendi, 1298: 8).

ayva (< Far. ābia, bia) “ayva" (EDPT: 268; Tietze, 2002: 168;

Eren, 1999: 29) $\rightarrow$ Kzk. ayva “ayva” (Koç, 2003: 29).

DLT'den itibaren görülmekte ve avya "ayva" şeklinde görülmektedir (Kaçalin, 2019: 86; Hauenschild, 1994: 34). Bununla birlikte Harezm Türkçesi eserlerinden ML'de ayva "ayva" (Battal, 1934: 14), Kıpçak Türkçesi eserlerinden GT'de ayva "ayva", TZ'de hayva "ayva" (Karamanlığlu, 1978: 211; Atalay, 1945: 173) şeklinde görülmektedir.

balturgan "baldıran, baldıran otu" (VEWT: 61; Baytop, 2015: 42; Tietze, 2002: 195) $\rightarrow$ Kzk. baldırǵan "çok yıllık otsu, çiçekli bir bitki; filiz" (Iskakov II, 2011: 680).

Sözcük Kıpçak Türkçesi eserlerinden Kİ baldaran "baldıran otu" (Caferoğlu, 1931: 36), Çağatay Türkçesi sözlüklerinden LÇT’de baldırg̀an "baldıran otu” (Şeyh Süleymān Efendi, 1298: 72) şeklinde görülmektedir.

bugday "buğday" (EDPT: 312; DTS: 120; Tietze, 2002: 319; Eren, 1999: 62) $\rightarrow$ Kzk. bugdday, biyday "buğday", Kazakçada yaygın kullanım biyday şeklindedir. Ancak bug்day şekli ağızlarda görülmektedir (Koç, 2003: 89; KTAS: 156).

Sözcük Eski Uygurca metinlerinden TT VII'de bugday "buğday", DLT ve KB'de bug்day "buğday" şeklinde görülmektedir (Wilkens, 2021: 196; Kaçalin, 2019: 125; 
Hauenschild, 1994: 40; Arat, 1979: 113). Harezm Türkçesi eserlerinden ML'de bug்day "buğday” (Battal, 1934: 22), Kıpçak Türkçesi eserlerinden CC'de boday, bog̀day, buggday "buğday" (Grønbech, 1942: 62) ve Çağatay Türkçesi eserlerinden MK ve LÇT'de buġday “buğday” (Ölmez, 1993: 414; Şeyh Süleymān Efendi, 1298: 82) şeklinde görülmektedir.

burçak "bezelye, nohut; hayvanlara yedirilen bir ot" (EDPT: 357; Tietze, 2002: 328) $\rightarrow$ Kzk. burşak "burçak, baklagiller familyasından bir bitki” (Koç, 2003: 99).

Sözcük, DLT'de burçak "börülce" şeklinde görülmektedir (Kaçalin, 2019: 129; Hauenschild, 1994: 41). Sözcük, Kıpçak Türkçesi eserlerinden TA'de burçak "bezelye, nohut" (Toparl,, 2000: 74), Çağatay Türkçesi sözlüklerinden LÇT'de burçak "nohuda benzer" (Şeyh Süleymān Efendi, 1298: 78) şeklinde görülmektedir.

bük "orman, ormanlık yer; çalılık” (EDPT: 324; DTS: 131; Tietze, 2002: 335) $\rightarrow$ Kzk. bük "kayın veya akgürgen ağacı türüne benzer bir ağaç; orman, çalılık" (KTAS: 163; Iskakov IV, 2011: $37)$.

Sözcük DLT'den itibaren görülmekte ve bük "sık ağaçlik" şeklinde geçmektedir (Kaçalin, 2019: 132). Sözcük Kıpçak Türkçesi eserlerinden KI'de bök “orman, birbirine girmiş çalı ve çırpı gibi yabani ağaçlar” (Caferoğlu, 1931: 21), Çağatay Türkçesi sözlüklerinden LÇT'de bük "orman" (Şeyh Süleymān Efendi, 1298: 83) şeklinde görülmektedir.

bür "tomurcuk" (EDPT: 354; DTS: 132) $\rightarrow$ Kzk. bür "tomurcuk" (Koç, 2003: 101).

Sözcük Eski Uygurcada bür "tomurcuk, demet, çiçek salkımı" şeklinde görülmektedir (Wilkens, 2021: 212). Sonraki süreçte Kıpçak Türkçesi eserlerinden CC'de bür "gonca, 
tomurcuk" şeklinde görülmektedir (Grønbech, 1942: 70). Bununla birlikte sözcük DLT'de bürlen- "tomurcuklanmak" ekleşmiş şekli de görülmektedir (Kaçalin, 2019: 134).

bürçek "dalların baş kısımları, tomurcuk kısımları" (EDPT: 357; Tietze, 2002: 337) $\rightarrow$ Kzk. bürşik "çiçeğin açmadan evvelki hali, tomurcuk" (Koç, 2003: 101).

Sözcük, Kıpçak Türkçesi eserlerinden TA bürçek "dalların baş kısmı" şeklinde görülmektedir (Toparlı, 2000: 82).

çağmur "şalgam, şalgamlık turp" (EDPT: 408; DTS: 136; Tietze, 2002: 346; Eren, 1999: 67) $\rightarrow$ Kzk. şomır "turp; havuç" (Koç, 2003: 643).

Sözcük DLT'de çag̀mur, çamġur “şalgam” şeklinde görülmektedir (Kaçalin, 2019: 137; Hauenschild, 1994: 42). Bununla birlikte Kıpçak Türkçesi eserlerinden TA'de çamg்ur, çomar "havuç" (Toparl1, 2000: 99-101), Çağatay Türkçesi sözlüklerinden LÇT'de çomur “şalgam” (Şeyh Süleymān Efendi, 1298: 109) şeklinde görülmektedir.

çęçek "çiçek" (EDPT: 400; DTS: 143; Tietze, 2002: 447; Eren, 1999: 91) $\rightarrow$ Kzk. şeşek "çiçek” (Koç, 2003: 639).

Sözcük Eski Türkçeden itibaren Türkçenin Tarihî ve çağdaş lehçelerinin hemen hepsinde görülmektedir. Sözcük Eski Uygurca metinlerinden U III ve TT V'de çeçek “çiçek", DLT ve KB'de çęçek "çiçek" şeklinde görülmektedir (Wilkens, 2021: 225; Kaçalin, 2019: 148; Arat, 1979: 131). Bununla birlikte sözcük, Harezm Türkçesi eserlerinden KE'de çęçek "çiçek", NF'de çiçek "çiçek" (Ata, 1997: 63; Ata, 1998: 56), Kıpçak Türkçesi eserlerinden CC ve TZ'de çiçek "çiçek", KK'de şişek "çiçek" (Grønbech, 1942: 75; Atalay, 1945: 239; Toparl1, 1999: 56) ve Çağatay Türkçesi eselerinden MK'de çiçek "çiçek" (Ölmez, 1993: 421) şeklinde görülmektedir. 
çım "çim, çimen” (EDPT: 421; Tietze, 2002: 451) $\rightarrow$ Kzk. şım "çim, çimen, çimenlik" (Koç, 2003: 653).

Sözcük DLT ve KB'de çim “ayrık otu, çim” şeklinde görülmektedir (Kaçalin, 2019: 155; Hauenschild, 1994: 45; Arat, 1979: 132). Sonrasında Kıpçak Türkçesi eserlerinden KI'de çim “çimen” şeklinde görülmektedir (Caferoğlu, 1931: 29).

çırpı "çalı çırpı, kuru ağaç" (Tietze, 2002: 444; Grønbech, 1942:

$79) \rightarrow$ Kzk. şırpı "çalı çırpı, kurumuş ağaç parçası" (Koç, 2003: $655)$.

Sözcük Kıpçak Türkçesi eserlerinden CC'de çırpı "çalı çırpı, kuru ağaç” (Grønbech, 1942: 79) ve Çağatay Türkçesi sözlüklerinden LÇT'de çırpı “çalı ve çırpı” (Şeyh Süleymān Efendi, 1298: 60) şeklinde görülmektedir.

çigit "pamuk çekirdeği”" (EDPT: 414; DTS: 145; Tietze, 2002: 448; Eren, 1999: 92) $\rightarrow$ Kzk. şiyit "pamuk çekirdeği, pamuk tohumu" (Iskakov XV, 2011: 375).

Sözcük DLT'den itibaren görülmekte ve çigit "pamuk çekirdeği” ş̧eklinde geçmektedir (Kaçalin, 2019: 154). Sözcük Kıpçak Türkçesi eserlerinden Kİde çikit "pamuğun tohumu" (Caferoğlu, 1931: 29) ve Çağatay Türkçesi sözlüklerinden LÇT'de çigit "çekirdek, pamuk çekirdeği" (Şeyh Süleymān Efendi, 1298: 163) şeklinde görülmektedir.

çikin "asmalar arasında yetişen bir bitki; başakları olan ve sığırlar tarafindan yenen bir bitki" (EDPT: 415) $\rightarrow$ Kzk. şigin "pirinç tarlasında büyüyen yabani bir ot” (KTAS: 779).

Sözcük DLT'de çigin 'üzüm bağlarında biten, hayvanların yediği başaklı bir ot; akdarı olarak bilinen otsu bir bitki” şeklinde görülmektedir (Kaçalin, 2019: 153; Hauenschild, 1994: 45). Ayrıca sözcük Çağatay Türkçesi sözlüklerinden LÇT'de çigin 'karabaş 
otu; çimenlik" şeklinde görülmektedir (Şeyh Süleymān Efendi, 1298: 163).

çor "çor ot = sık bitki örtüsü, sarmaşık" (EDPT: 427; DTS: 154) $\rightarrow$

Kzk. şor "sarmaşık, ağaçların dibinde yetişen ve onlara sarılan bir bitki" (Iskakov XV, 2011: 402).

Sözcük yalnızca DLT'de çor ot "sarılgan bir bitki, sarmaşık" şeklinde görülmektedir (Kaçalin, 2019: 157).

çökür "bir çeşit diken; diken" (Tietze, 2002: 466; Eren, 1999: 99;

VEWT: 121) $\rightarrow$ Kzk. şögir "bir tür diken; diken, kıymık" (Iskakov XV, 2011: 412).

Sözcük Kıpçak Türkçesi eserlerinden TZ'de çokur "bir tür diken" (Atalay, 1945: 162) ve Çağatay Türkçesi eserlerinden MK, LÇT'de çökür "diken" (Ölmez, 1993: 421; Şeyh Süleymān Efendi, 1298: 157) şeklinde görülmektedir.

deygel "ekin saplarının boğumu" (EDPT: 520; DTS: 158) $\rightarrow$ Kzk. deygel "saman çöpü; çok yıllık otsu bir bitki" (Iskakov IV, 2011: 638).

Sözcük yalnızca DLT'de dangal "ekin saplarının boğumu" şeklinde görülmektedir (Kaçalin, 2019: 162).

emen "meşe, ağaç (Toparl1, 2000: 109) $\rightarrow$ Kzk. emen "meşe, meşe ağacı" (Koç, 2003: 139).

Sözcük yalnızca Kıpçak Türkçesi eserlerinden TA'de emen “meşe, ağaç” şeklinde görülmektedir (Toparlı, 2000: 109).

erïk "çekirdekli meyve; erik, kayıs1 gibi meyvelere verilen genel ad" (EDPT: 222; DTS: 182; Tietze, 2002: 737; Eren, 1999: 137)

$\rightarrow$ Kzk. erik, örik “erik; şeftali” (KTAS: 217; Koç, 2003: 432). 
Sözcük, Türkçenin tarihî dönemlerinin hemen hepsinde görülmektedir. Sözcük Eski Uygurca eserlerinden TT VIII'de erük “erik, kayısı; meyve ağacı”, DLT'de erük “şeftali, kayısı, erik gibi meyvelerin genel adı" şeklinde görülmektedir (Wilkens, 2021: 121; Kaçalin, 2019: 174; Hauenschild, 1994: 45). Kıpçak Türkçesi eserlerinden CC'de erik “erik", KI' de erük "erik" (Grønbech, 1942: 92; Caferoğlu, 1931: 36), Çağatay Türkçesi sözlüklerinden LÇT’de erik “erik, kayısı” (Şeyh Süleymān Efendi, 1298: 9) şeklinde görülmektedir.

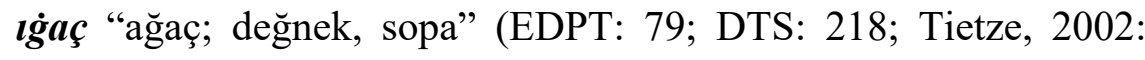
$109) \rightarrow$ Kzk. ag̉aş "ağaç" (Koç, 2003: 25).

Sözcük, Türkçenin tarihî ve çağdaş lehçelerinin hemen hepsinde görülmektedir. Sözcük Orhun Yazıtlarında ı่̇aç "ağaç" (Tekin, 2017: 92), Eski Uygurca eserlerden TT I'de ì่aç "ağaç", DLT ve KB'de yı ̇̇aç “ağaç” (Wilkens, 2021: 287; Kaçalin, 2019: 590; Arat, 1979: 538) şeklinde görülmektedir. Bununla birlikte

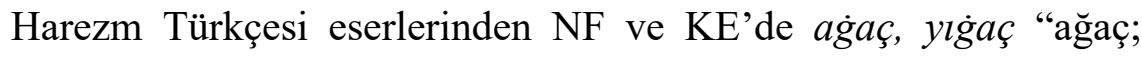
değnek, sopa" (Ara, 1997: 476; Ata, 1998: 482), Kıpçak Türkçesi eserlerinden CC ve Kİ'de ağaç "ağaç" (Grønbech, 1942: 28; Caferoğlu, 1931: 1), Çağatay Türkçesi eserlerinden MK'de yı $\dot{g} a c ̧$

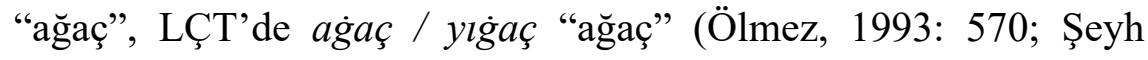
Süleymān Efendi, 1298: 15) şeklinde görülmektedir.

ıs ġun (< Far. aşxuwān) "kuzukulağı, 1şkın” (EDPT: 259; DTS: 220; Tietze, 2009: 359; Eren, 1999: 184) $\rightarrow$ Kzk. ışkıın "püsküllü, çiçeği kırmızı renkli olan bir bitki" (Iskakov XV, 2011: 689).

Sözcük, DLT'de ışg்n “1şkın otu” şeklinde görülmektedir (Kaçalin, 2019: 195; Hauenschild, 1994: 48).

it üzümi “yabani üzüm” (Rachmati, 1932: 408; DTS: 215) $\rightarrow$ Kzk. it jüzim "yabani üzüm; nemli yerlerde yetişen bir tür bitki" (Iskakov VII, 2011: 377). 
Sözcük Eski Uygurcada it üzümi "yabani üzüm” şeklinde görülmektedir (Rachmati, 1932: 408). Bununla birlikte Çağatay Türkçesi sözlüklerinden LÇT'de it üzümi “süs üzümü” şeklinde görülmektedir (Şeyh Süleymān Efendi, 1298: 46).

it burnı "kuşburnu, it burnu; yaban gül meyvesi, çiçeği" (DTS: $215) \rightarrow$ Kzk. it murın "yaprakları kırmız1, meyvesi olan bir çiçek, yaban çiçeği”" (Iskakov VII, 2011: 380).

Sözcük Eski Uygurcada it burnı "kuşburnu, itburnu" şeklinde görülmektedir (Wilkens, 2021: 291). Bununla birlikte Kıpçak Türkçesi eserlerinden İH'de it burnu "yabani gül” (İzbudak, 1936: 26), Çağatay Türkçesi sözlüklerinden LÇT'de it burnı "nesrin tohumu" (Şeyh Süleymān Efendi, 1298: 46) şeklinde görülmektedir.

kad $\underline{d} \boldsymbol{\prime}$ "kayın ağacı" (EDPT: 602; DTS: 404; Eren, 1999: 222) $\rightarrow$ Kzk. kayıı "kayın ağacı" (Koç, 2003: 276).

Sözcük, Eski Uygurca metinlerde kad ı̋ "kayın ağacı" (Rachmati, 1930: 460), DLT'de kad $ı \eta^{\prime}$ "kayın ağacı” (Kaçalin, 2019: 209; Hauenschild, 1994: 54), KB'de kadı $ı$ "kayın ağacı" (Arat, 1979: 214) şeklinde görülmektedir. Ayrıca sözcük, Kıpçak Türkçesi eserlerinden TA'de kayın "kayın ağacı", CC'de kayı "kayın ağacı", DM'de kayın ag்aşı "kayın ağacı" (Toparlı, 2000: 96; Grønbech, 1942: 191), Çağatay Türkçesi eserlerinden Şecere-i Terākime'de kayı "kayın ağacı” (Ölmez, 1996: 394) şeklinde görülmektedir.

kavuz "tah11, darı kabuğu" (Eren, 1999: 220; Pavet de Courteille, 1870: 413) $\rightarrow$ Kzk. kavız "tahıl kabuğu; gonca, tomurcuk" (Koç, 2003: 303).

Sözcük Çağatay Türkçesi sözlüklerinden LÇT'de ķavuz "tahıl, darı kabuğu; buğday, arpa, yulaf, çavdar, pirinç gibi 
ekinlerin başağında, başakçıkları veya çiçeği saran kabuk" (Şeyh Süleymān Efendi, 1298: 224).

kavık "darı kepeği, kepek” (EDPT: 583; DTS: 436) $\rightarrow$ Kzk. kavık "buğday, darı gibi hububatların kepeği”" (KTAS: 404).

Sözcük, Eski Uygurca metinlerinden TT VII'de kavık "darı kepeği” (Wilkens, 2021: 347), KB'de kavuk "kepek”, DLT'de kavık "darı kepeği” (Arat, 1979: 229; Kaçalin, 2019: 233) şeklinde görülmektedir. Ayrıca sözcük Kıpçak Türkçesi eserlerinden BV ve KI'de kavuk "kavut, öğütülüp kavrulmuş buğday ve arpa" şeklinde görülmektedir (Ağar, 1986: 208; Caferoğlu, 1931: 73).

kagiun "kavun" (EDPT: 611; DTS: 406; Eren, 1999: 220) $\rightarrow$ Kzk. kavın "kavun" (Koç, 2003: 304).

Sözcük, Eski Uygurca metinlerinden TT III'de kag்un "kavun" (Wilkens, 2021: 319), DLT ve KB'de kagun "kavun" (Kaçalin, 2019: 211; Hauenschild, 1994: 55; Arat, 1979: 215) şeklinde görülmektedir. Sözcük Harezm Türkçesi eserlerinden KE'de kaġun "kavun” (Ata, 1997: 251), Kıpçak Türkçesi eserlerinden CC'de kovun / huvun "kavun", KI'de kavun "kavun" (Grønbech, 1942: 201; Caferoğlu, 1931: 73), Çağatay Türkçesi eserlerinden Babür Divanı'nda kaġun “kavun” (Yücel, 1995: 354) şeklinde görülmektedir.

kamg்k "çalı çırpı; semer otu; deve dikeni" (EDPT: 627; DTS: $415) \rightarrow$ Kzk. kamġak, kạbak "çalı çırpı; deve dikeni" (KTAS: 380; Iskakov IX, 2011: 245).

Sözcük, Eski Uygurca metinlerinden TT I'de kamgak "bir tür çimen; dikenli çöven" (Wilkens, 2021: 326), DLT'de kamg்ak "evlerin delik ve yarıklarını kapadığı zayıf bir ot" (Kaçalin, 2019: 216; Hauenschild, 1994: 55) şeklinde görülmektedir. Harem Türkçesi eserlerinden HŞ’de kamgak "sarımsak" (Hacıeminoğlu, 2000: 284), Kıpçak Türkçesi eserlerinden TA'de kamkak 'ç̧alı 
çırpı" (Toparlı, 2000: 125), Çağatay Türkçesi eserlerinden MK'de kamġak "deve dikeni” (Ölmez, 1993: 468) şeklinde görülmektedir.

kamış "kamış, saz" (EDPT: 628; DTS: 415; Eren, 1999: 204) $\rightarrow$ Kzk. kamıs "kamış, sazlık” (Koç, 2003: 283).

Sözcük, Eski Uygurca metinlerinden Irk Bitig'de kamış / kamuş "kamış, saz, sazlık" (Tekin, 2013: 54-55), DLT'de kamış "kamış, kamışl1k" (Kaçalin, 2019: 217; Hauenschild, 1994: 56) şeklinde görülmektedir. Sözcük Harezm Türkçesi eserlerinden ML'de kamış "kamış" (Battal, 1934: 37), Kıpçak Türkçesi eserlerinden CC, GT ve TZ'de ḳamış "şeker kamışı, sazlık" (Grønbech, 1942: 192; Karamanlığlu, 1978: 287; Atalay, 1945: 183), Çağatay Türkçesi eserlerinden MK'de ḳamış "kamış" (Ölmez, 1993: 468) şeklinde görülmektedir.

kapak, kabak "kabak (sebze)" (EDPT: 582; DTS: 399; Eren, 1999: $199) \rightarrow$ Kzk. kabak "kabak” (Koç, 2003: 267).

Sözcük, Eski Uygurcada kabak / ḳapak "kabak, kabak çiçeği”" (Wilkens, 2021: 331), DLT'de kapak 'kabak, yaş iken yemeği yapılan bir sebze" (Kaçalin, 2019: 220; Hauenschild, 1994: 54) şeklinde görülmektedir. Sözcük Kıpçak Türkçesi eserlerinden CC ve TZ'de kabak "kabak (sebze)" şeklinde görülmektedir (Grønbech, 1942: 188; Atalay, 1945: 181).

kara erük "siyah erik" (EDPT: 643; DTS: 422) $\rightarrow$ Kzk. ḳara örik "siyah erik, mürdüm eriği” (Koç, 2003: 292).

Sözcük, Harezm Türkçesi eserlerinden ML'de kara ürük "siyah erik" şeklinde görülmektedir (Battal, 1934: 37). Bununla birlikte sözcük, Kıpçak Türkçesi eserlerinden DM'de kara erük “kara erik” şeklinde görülmektedir (Toparl1, 2003: 88).

kara ot "Hindistan'dan gelen zehirli bir bitki, baldıran otu" (EDPT: 643; DTS: 422) $\rightarrow$ Kzk. kara ot "semizotugiller sinıfından, tadı acı olan bitki” (Iskakov IX, 2011: 347). 
Sözcük, DLT'de kara ot "Hindistan'dan gelen zehirli bir bitki, baldıran otu" şeklinde görülmektedir (Kaçalin, 2019: 222).

karagan "kisa boylu, dikenli bir bitki" (DTS: 425) $\rightarrow$ Kzk. karaġan "kısa boylu, çok dallı dikenli bir bitki" (Koç, 2003: 290).

Sözcük, DLT'de karakan "bir dağ ağacı türü” şeklinde görülmektedir (Kaçalin, 2019: 222; Hauenschild, 1994: 56).

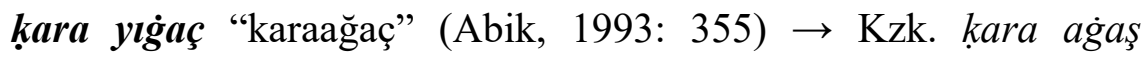
"karağaç" (Koç, 2003: 290).

Sözcük Çağatay Türkçesi eserlerinden Tarih-i Enbiya ve Hükema adlı eserde kara yı ̇̇aç "karaağaç" şeklinde görülmektedir (Abik, 1993: 355).

karamuk "it üzümü; buğdayın içersinde yer alan taneler" (EDPT: 660; DTS: 424) $\rightarrow$ Kzk. ḳaramık "yaban mersini, keçi yemişi" (Koç, 2003: 292).

Sözcük, DLT'de ķaramuk 'karamuk, buğday içerisinde yer alan karamuk taneleri” şeklinde görülmektedir (Kaçalin, 2019: 223; Hauenschild, 1994: 57). Sözcük Kıpçak Türkçesi eserlerinden İH'de karamuk "gülçer denilen karaca tohum" (İzbudak, 1936: 27), Çağatay Türkçesi sözlüklerinden LÇT'de karamug “buğdayın içinde yer alan siyah taneler" (Şeyh Süleymān Efendi, 1298: 216) şeklinde görülmektedir.

kavak, kabak "kavak, kavak ağacı" (Eren, 1999: 219) $\rightarrow$ Kzk. kuvak "kavak ağacı" (Iskakov X, 2011: 174).

Sözcük, Harezm Türkçesi eserlerinden KE'de kabak 'kavak, kavak ağacı" (Ata, 1997: 276), Kıpçak Türkçesi eserlerinden TA'de kavak "kavak, kava ağacı" (Toparlı, 2000: 132) şeklinde görülmektedir. 
kavla, kalva "sebze, yeşillik" (EDPT: 584; DTS: 437) $\rightarrow$ Kzk. kavla "gür ve sık çıkan ot, yeşillik" (Iskakov IX, 2011: 496) . Hatta Kazakçada kavla- "(ot) gür ve sık çıkmak" fiili de vardır (Koç, 2003: 303).

Sözcük Eski Uygurcada kavla / kalva "sebze, yeşillik" şeklinde görülmektedir (Wilkens, 2021: 324).

kavra, kavray"sarı renkli büyük bitki” (ESTY V: 171) $\rightarrow$ Kzk. kuvray "kamış gibi uzun, büyük bir bitki” (Iskakov X, 2011: 205).

Sözcük, Kıpçak Türkçesi eserlerinden Kİde kavra "sarı renkli bitki, saman” şeklinde görülmektedir (Caferoğlu, 1931: 76).

kekre "ilaç yapımında da kullanılan, tadı ekşi veya acı olan bir bitki" (EDPT: 712; DTS: 295) $\rightarrow$ Kzk. kekire "peygamber çiçeği; develerin yediği bir tür ot; ekinlerin arasından çıkan tadı acı bir bitki” (Koç, 2003: 225; Iskakov VII, 2011: 760).

Sözcük, Eski Uygurcada kekre "tadı acı şifalı bir bitki" (Rachmati, 1932: 406), DLT'de kekre "develerin yediği acı bir ot" (Kaçalin, 2019: 242; Hauenschild, 1994: 49) şeklinde görülmektedir. Ayrıca sözcük, Çağatay Türkçesi sözlüklerinden LÇT'de kekre "bir acı ot” şeklinde görülmektedir (Şeyh Süleymān Efendi, 1298: 254).

kendir "kendir, kenevir; keten" (EDPT: 729; DTS: 298; Eren, 1999: 230) $\rightarrow$ Kzk. kendir "kendir, kenevir". Ayrıca sözcük Kazakçada kendir "kenevirden yapılmış ip, urgan" anlamında da kullanılmaktadır (Koç, 2003: 228).

Sözcük, Eski Uygurca metinlerinden TT VII'de kendir "kenevir tohumu" şeklinde görülmektedir (Rachmati, 1932: 122; Wilkens, 2021: 356). Sözcük, Kıpçak Türkçesi eserlerinden CC, Kİ ve TZ'de kendir "kendir" (Grønbech, 1942: 138; Caferoğlu, 1931: 44; Caferoğlu, 1945: 194), Çağatay Türkçesi sözlüklerinden 
LÇT'de kendir "keten, keten tohumu" (Şeyh Süleymān Efendi, 1298: 255) şeklinde görülmektedir.

keşür, geşür (< Far. gezer) "havuç" (Eren, 1999: 234) $\rightarrow$ Kzk. keşir "havuç" (KTAS: 327).

Sözcük, DLT'de geşür "havuç" şeklinde görülmektedir (Kaçalin, 2019: 189). Ayrıca sözcük, Harezm Türkçesi eserlerinden ML'de keşir “havuç” (Battal, 1934: 41), Kıpçak Türkçesi eserlerinden Kİ ve TZ'de keşür "havuç” (Caferoğlu, 1931: 46; Atalay, 1945: 196), Çağatay Türkçesi sözlüklerinden LÇT'de keşir "havuç, sebze" (Şeyh Süleymān Efendi, 1298: 254) şeklinde görülmektedir.

kevrik "çalı görünümlü, çok yıllık tıbbi bir bitki, hayıt; deve elması" (EDPT: 690; DTS: 304) $\rightarrow$ Kzk. kevrek "kumlu yerde yetişen, ilaç için kullanılan dikenli bir bitki; çakşır” (Iskakov VII, 2011: 737).

Sözcük, DLT'de kevrik “diken, çakırdiken” şeklinde görülmektedir (Kaçalin, 2019: 253; Hauenschild, 1994: 51).

kèyikotı "kekik, hoş kokulu bir bitki" (EDPT: 755; DTS: 295) $\rightarrow$ Kzk. kiyik otı "dağda yetişen hoş kokulu bir bitki" (Iskakov VIII, 2011: 43).

Sözcük, DLT'de keyik olarak geçmekte ve 'yabani olan her şey’ için kullanılmaktadır (Kaçalin, 2019: 253).

kıçı "hardal” (EDPT: 590; DTS: 440; Eren, 1999: 235) $\rightarrow$ Kzk. kışa "hardal otu" (Koç, 2003: 353).

Sözcük, DLT'de ḳıçı “hardal” şeklinde görülmektedir (Kaçalin, 2019: 269; Hauenschild, 1994: 60). Ayrıca sözcük, Harezm Türkçesi eserlerinden ML'de kııç "hardal” (Battal, 1934: 42), Kıpçak Türkçesi eserlerinden TZ'de kııç / kıış "hardal” (Atalay, 1945: 198), Çağatay Türkçesi sözlüklerinden LÇT’de kıçı 
"hindibaya benzer bir çeşit bitki" (Şeyh Süleymān Efendi, 1298: 244) şeklinde görülmektedir.

kımızdık "kuzukulağı” (VEWT: 264) $\rightarrow$ Kzk. ǩımızdık "tadı ekşi bir ot; kuzukulağg”" (Koç, 2003: 374).

Sözcük, Türkçenin tarihî ve çağdaş lehçelerinde görülen kıımız sözcügünden gelmektedir. Kımızın ekşi bir tat olması kuzukulağının tadının da kımıza benzemesi bu sözcüğün oluşmasına neden olmuştur. Kımızdık (kuzukulağı) sözcüğün anlamı "kımız gibi, kımız gibi ekşi" olarak verilebilir. Ayrıca Kazaklar, kımızın tadını ekşitebilmek için kımızdık (kuzukulağı) dedikleri bitkiyi içine katarlar.

kıyak "kamış, saz, ot” (ESTY VI: 201) $\rightarrow$ Kzk. ḳıyak "sazlık, kamış; çayırlık, ot” (Iskakov IX, 2011: 597).

Sözcük Çağatay Türkçesinde klyak "kamış, saz, ot" şeklinde görülmektedir (Pavet de Courteille, 1870: 443).

kııalak (< ḳız + alaḳ) "kırmızı renkli bir çiçek" (Durgut, 1995: $502) \rightarrow$ ḳzanak (< ḳı + anak) "domates, kırmızı renkli bir bitki” (Koç, 2003: 342). Sözcük Kazakçada, kız- fiiline -anak yapım ekinin getirilmesiyle oluşturulmuştur (Öner, 2013: 93).

Sözcük, Çağatay Türkçesi sözlüklerinden LÇT'de ḳıalag "kırmızı renkli bir çiçek" şeklinde görülmektedir (Şeyh Süleymān Efendi, 1298: 246).

kıığaldak "lale" (ESTY VI: 191) $\rightarrow$ Kzk. ḳzġaldak "lale" (Koç, 2003: 342).

Sözcük, Çağatay Türkçesinde ḳzalak "lale” şeklinde görülmektedir (Pavet de Courteille, 1870: 447). 
koban "büyük, iri taneli bir buğday" (Şeyh Süleymān Efendi, 1298: $230) \rightarrow$ Kzk. koban, kobay"iri taneleri olan bir buğday çeşidi”" (KTAS: 412).

Sözcük, Çağatay Türkçesi sözlüklerinden LÇT'de ķoban "büyük, iri taneli bir buğday" şeklinde görülmektedir (Şeyh Süleymān Efendi, 1298: 230).

$\boldsymbol{k} \boldsymbol{o} \dot{\boldsymbol{g}} \boldsymbol{a}$ "su kamış1, saz, hasır otu" (ESTY VI: 10; VEWT: 275) $\rightarrow$ Kzk. kog $\dot{a} a$ "su kamış1, saz” (Koç, 2003: 310).

Sözcükle ilgili en açık bilgiyi Türk Dilinin Etimolojik Sözlügü̈nden görmekteyiz. Burada sözcügün kökeninin belli olmadığı ve çağdaş lehçelerde kullanıldığı belirtilmiştir (Eren, 1999: 249).

konak "bir tür darı" (EDPT: 637; DTS: 455) $\rightarrow$ Kzk. konak "darının bir türü; bir çeşit pırasa" (Koç, 2003: 316; Iskakov X, 2011: 26).

Sözcük, Eski Uygurca metinlerden TT VII'de konak "darı çeşidi" (Wilkens, 2021: 391), DLT'de ķonak "bir çeşit kaba darı" (Kaçalin, 2019: 276; Hauenschild, 1994: 60) şeklinde görülmektedir. Sözcük, Harezm Türkçesi eserlerinden KE'de ķonak "bir tür ufak darı" (Ata, 1997: 334), Kıpçak Türkçesi eserlerinden İH'de konak tarig "bir cins darı" (İzbudak, 1936: 31), Çağatay Türkçesi sözlüklerinden LÇT'de konag "bir tür darı" (Şeyh Süleymān Efendi, 1298: 240) şeklinde görülmektedir.

kök "yeşil, yeşillik, ot” (EDPT: 708; DTS: 312) $\rightarrow$ Kzk. kök "yeşil, çimen; sebze, meyve" (Koç, 2003: 243).

Sözcük, ET'den itibaren Türkçenin tüm tarihi dönemlerinde kök “gök, gökyüzü; mavi, yeşil; asıl, kök” gibi şekillerde görülmektedir. Ancak Harezm Türkçesi eserlerinden ME'de kök "yeşil, ot" (Ata, 1997: 340), Çağatay Türkçesi sözlüklerinden 
LÇT’de kök “yeşil, yeşillik” (Şeyh Süleymān Efendi, 1298: 259) şeklinde görülmektedir.

köken, kögen "şeftali; gövem eriğii” (Atalay, 1945: 206) $\rightarrow$ Kzk. köken "ceviz, zeytin gibi yuvarlak şekilli bir meyve; çalı, kısa ağaç” (Iskakov VIII, 2011: 235).

Sözcük, Kıpçak Türkçesi eserlerinden TA'de köken “şeftali", TZ'de kögen, kögem "gövem eriği” (Atalay, 1945: 206; Toparl1, 2000: 122), Çağatay Türkçesi sözlüklerinden LÇT'de kögem "sert bir ağaç" (Şeyh Süleymān Efendi, 1298: 259) şeklinde görülmektedir.

kömürgen "dağ soğanı” (EDPT: 691; DTS: 326; Eren, 1999: 257) $\rightarrow$ Kzk. köbürgen, kömürgen "dağ soğanı; dağ sarımsă̆ı" (KTAS: 329).

Sözcük, sadece DLT'de kömürgen, kövürgen şeklinde geçmekte ve 'dağ soğanı' anlamında kullanılmaktadır (Kaçalin, 2019: 292; Hauenschild, 1994: 52).

kumlak "kendirgiller familyasından bir bitki, şerbetçi otu" (EDPT: 628; DTS: 466) $\rightarrow$ Kzk. kulmak "ilaç yapımında kullanılan, uzun saplı, dikenli bir bitki” (Iskakov X, 2011: 307).

Sözcük, DLT'de kumlak 'Kıpçak illerinde yetişen, yaprağı fasulye yaprağına benzer sarmaşık gibi bir ot" şeklinde görülmektedir (Kaçalin, 2019: 302; Hauenschild, 1994: 61). Bununla birlikte sözcük, Çağatay Türkçesinde kulmak "bir tür ot" şeklinde görülmektedir (Pavet de Courteille, 1870: 436).

malguna "1lgın ağacına benzer bir bitki" (DTS: 335; VEWT: 324) $\rightarrow$ Kzk. balġın "bir tür bitki, ağaç" (Koç, 2003: 77).

Sözcük, DLT'de malguna / bulg்una “1lgın ağacına benzer ağaç” şeklinde görülmektedir (Kaçalin, 2019: 127; Hauenschild, 1994: 40). 
mirç, murç (< Sans. marica, marīca) "biber, karabiber" (EDPT:

771; DTS: 346) $\rightarrow$ Kzk. burış "karabiber, biber" (Koç, 2003:

99).

Sözcük, Eski Uygurca metinlerinden TT VII'de murç "karabiber" (Wilkens, 2021: 476), DLT'de murç "biber" (Kaçalin, 2019: 331; Hauenschild, 1994: 63) şeklinde görülmektedir. Sözcük, Kıpçak Türkçesi eserlerinden CC ve Kİ'de burç "karabiber" (Grønbech, 1942: 69; Caferoğlu, 1931: 23), Çağatay Türkçesi sözlüklerinden LÇT'de borc / burc “biber” (Şeyh Süleymān Efendi, 1298: 78) şeklinde görülmektedir.

orman "orman" (Eren, 1999: 309) $\rightarrow$ Kzk. orman "orman” (Koç, 2003: 417).

Sözcük Harem Türkçesi eserlerinden NF'de orman “orman” (Ata, 1998: 128), Kıpçak Türkçesi eserlerinden CC ve Kİde orman “orman, ağaç kümesi” (Grønbech, 1942: 179; Caferoğlu, 1931: 63) şeklinde görülmektedir.

ot "bitki, ot" (EDPT: 34; DTS: 373; Eren, 1999: 310) $\rightarrow$ Kzk. ot “ot” (Koç, 2003: 419).

Sözcük, Eski Uygurca metinlerde TT V ot "ot, yeşillik" (Clauson, 1972: 34-35), DLT'de ot “ot” (Kaçalin, 2019: 361) şeklinde görülmektedir. Sözcük, Harezm Türkçesi eserlerinden NF ve KE'de ot "ot, nebat" (Ata, 1997: 451; Ata, 1998: 523), Kıpçak Türkçesi eserlerinden CC ve KI'de ot "ot, yabani bitki”" (Grønbech, 1942: 180; Caferoğlu, 1931: 63), Çağatay Türkçesi sözlüklerinden LÇT'de ot "ot, bitki, çayır; zehir" (Şeyh Süleymān Efendi, 1298: 24) şeklinde görülmektedir.

öley "çim, çimen, taze yeşil ot” (EDPT: 147) $\rightarrow$ Kzk. öley "sulak yerde yetişen ot, çimen” (Iskakov XII, 2011: 131).

Sözcük Eski Uygurcada öley "çimen, çayır" şeklinde görülmektedir (Wilkens, 2021: 530). Sözcük, Çağatay Türkçesi 


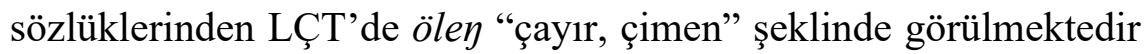
(LÇT, 1289: 39).

özek "ağacın bedeni, özü" (EDPT: 285; DTS: 395) $\rightarrow$ Kzk. özek "bitkilerin kök, gövde ve dallarının ortasında boydan boya bulunan hafif, gevrek ve çoğu yumuşak bölüm, öz” (Koç, 2003: 424).

Sözcük, Kıpçak Türkçesi eserlerinden TZ'de özek "ağacın bedeni, özü”, İH'de özdek “ağacın bedeni, özü” (Atalay, 1945: 228; İzbudak, 1936: 37), Çağatay Türkçesi sözlüklerinden LÇT’de özek "bir şeyin içi, çekirdek” (Şeyh Süleymān Efendi, 1298: 32) şeklinde görülmektedir.

sagiz, sakız "sakız" (EDPT: 817; DTS: 481; Eren, 1999: 351) $\rightarrow$ Kzk. sağız "sakız” (Koç, 2003: 458).

Sözcük Eski Uygurcada saḳı "sakız" (Rachmati, 1932: 137), DLT'de saǵlz / sakıı “sakız” (Kaçalin, 2019: 386) şeklinde görülmektedir. Ayrıca sözcük, Harezm Türkçesi eserlerinden ML'de saḳz "sakız" (Battal, 1934: 58), Kıpçak Türkçesi eserlerinden CC'de sakız "sakız", İM'de sağız "sakız" (Toparlı, 1992: 586; Grønbech, 1942: 214).

saz "kamış, ot, bataklık" (VEWT: 406) $\rightarrow$ Kzk. saz "kamış, sazlık, bataklık; çayır" (Koç, 2003: 459; KTAS: 571).

Sözcük, Harezm Türkçesi eserlerinden HŞ’de saz "kamış, ot, sazlık" (Hacıeminoğlu, 2000: 307), Kıpçak Türkçesi eserlerinden Kİ'de saz "orman", CC'de saz "batakl1k" (Grønbech, 1942: 216; Caferoğlu, 1931: 88), Çağatay Türkçesi sözlüklerinden LÇT'de saz "hasır otu, kamış" (Şeyh Süleymān Efendi, 1298: 179) şeklinde görülmektedir.

sarumsak "sarımsak" (EDPT: 853; DTS: 489; Eren, 1999: 357) $\rightarrow$ Kzk. sarımsak "sarımsak" (Koç, 2003: 470). 
Sözcük DLT'de sarmusak / samursak "sarımsak" şeklinde görülmektedir (Kaçalin, 2019: 393; Hauenschild, 1994: 66). Ayrıca sözcük, Harem Türkçesi eserlerinden ML'de sarımsak "sarımsak", KE'de sarmusak "sarımsak" (Battal, 1934: 59; Ata, 1997: 603), Kıpçak Türkçesi eserlerinden Kİ ve TZ'de sarımsak "sarımsak", CC'de sarmisak "sarımsak" (Grønbech, 1942: 214; Caferoğlu, 1931: 87; Atalay, 1945: 233), Çağatay Türkçesi sözlüklerinden LÇT’de sarımsak "sarımsak” (Şeyh Süleymān Efendi, 1298: 179) şeklinde görülmektedir.

sog்an, sag்un "soğan" (EDPT: 812; DTS: 507; Eren, 1999: 372) $\rightarrow$ Kzk. sog̀an "bahçede, tarlada yetişen bir bitki" (KTAS: 602).

Sözcük, Eski Uygurcada soġun "soğan" (Rachmati, 1932: 128), DLT'de soġan / soġon “soğan” (Kaçalin, 2019: 414; Hauenschild, 1994: 69) şeklinde görülmektedir. Sözcük, Harezm Türkçesi eserlerinden ML'de soġan "soğan” (Battal, 1934: 62), Kıpçak Türkçesi eserlerinden CC ve TZ'de soġan "soğan" (Grønbech, 1942: 221; Atalay, 1945: 239), Çağatay Türkçesi sözlüklerinden LÇT'de soġan “soğan” (Şeyh Süleymān Efendi, 1298: 191) şeklinde görülmektedir.

sögüt "sögüut ağac1" (EDPT: 819; DTS: 510; Eren, 1999: 375) $\rightarrow$ Kzk. sävit "sögüt ağacı" (KTAS: 595).

Sözcük, Eski Uygurca metinlerden TT I'de sögüt "söğüt ağacı" (Clauson, 1972: 819), DLT'de sögüt "söğüt ağacı" (Kaçalin, 2019: 417; Hauenschild, 1994: 69) şeklinde görülmektedir. Ayrıca sözcük Harezm Türkçesi eserlerinden ME'de sögüt "ağaç" (Yüce, 1993: 177), Kıpçak Türkçesi eserlerinden TA'de sögüt "sögüt ağacı" (Toparl1, 2000: 274), Çağatay Türkçesi sözlüklerinden LÇT'de sögüd "söğüt ağacı" (Şeyh Süleymān Efendi, 1298: 192) şeklinde görülmektedir. 


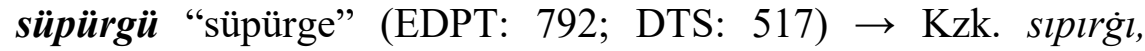
sıpırğıs, sıpırtḳ "süpürge, süpürge otu” (Iskakov XIII, 2011: 534-535).

Sözcük DLT'de süpürgü "süpürge" şeklinde görülmektedir (Kaçalin, 2019: 428). Harezm Türkçesi eserlerinden ML'de süpürgü "süpürge" (Battal, 1934: 65), Kıpçak Türkçesi eserlerinden Kİ'de süpürge "süpürge", TZ'de sipirge / sipirgi “süpürge", CC'de sibürtki "süpürge" (Caferoğlu, 1931: 94; Atalay, 1945: 239; Grønbech, 1942: 219), Çağatay Türkçesi sözlüklerinden LÇT’de süpürgü “süpürge” (Şeyh Süleymān Efendi, 1298: 188) şeklinde görülmektedir.

tal "sögüt ağacı" (EDPT: 489) $\rightarrow$ Kzk. tal "yaş dalları olan, ince yapraklı ağaç, söğüt” (Koç, 2003: 514; Iskakov XIII, 2011: 645).

Sözcük, Harezm Türkçesi eserlerinden NF'de tal "ağaç" (Ata, 1998: 401), Kıpçak Türkçesi eserlerinden GT'de tal "söğüt" (Karamanlıoğlu, 1978: 368), Çağatay Türkçesi sözlüklerinden LÇT'de tal "söğüt ağacı" (Şeyh Süleymān Efendi, 1298: 102) şeklinde görülmektedir.

tarı $\dot{\boldsymbol{g}}$ "arpa, buğday, darı; ekin, bitki” (EDPT: 537; DTS: 537; Eren, 1999: 105) $\rightarrow$ Kzk. tarl "darı, akdarı" (Koç, 2003: 524; Iskakov XIV, 2011: 16).

Sözcük Eski Uygurca metinlerinden Irk Bitig'de tarlg “ekin” (Tekin, 2013: 61), DLT'de tarig “ekin, bitki; arpa, buğday” (Kaçalin, 2019: 443; Hauenschild, 1994: 73) şeklinde görülmektedir. Sözcük, Harezm Türkçesi eserlerinden NF'de tarı̀ "buğday”, KE'de tarlk "buğday" (Ata, 1997: 599; Ata, 1998: 405), Kıpçak Türkçesi eserlerinden CC, Kİ ve TZ'de tarl "darı" (Grønbech, 1942: 236; Caferoğlu, 1931: 99; Atalay, 1945: 252), Çağatay Türkçesi eserlerinden LD'de tarl “darı, ekin” (Karaağaç, 1997: 358) şeklinde görülmektedir. 
tavılku "kızıl ağaç" (EDPT: 440; DTS: 542) $\rightarrow$ Kzk. tobılg̈ "kızılcık ağacı" (Koç, 2003: 538).

Sözcük, DLT'de tavulkı "hünnap, çiğde” şeklinde görülmektedir (Kaçalin, 2019: 451; Hauenschild, 1994: 74).

tèrek "ağaç, kavak ağacı" (EDPT: 543; DTS: 553) $\rightarrow$ Kzk. terek “kavak, kavak ağacı” (Koç, 2003: 535).

Sözcük, DLT'de tèrek “kavak" şeklinde görülmektedir (Kaçalin, 2019: 465; Hauenschild, 1994: 75). Sözcük, Harezm Türkçesi eserlerinden KE'de terek "asma" (Ata, 1997: 387), Kıpçak Türkçesi eserlerinden CC, Kİ ve TZ'de terek "ağaç, hurma ağacı" (Grønbech, 1942: 242; Caferoğlu, 1931: 102; Atalay, 1945: 256), Çağatay Türkçesi sözlüklerinden LÇT'de terek / tirek "servi, kavak" (Şeyh Süleymān Efendi, 1298: 108) şseklinde görülmektedir.

tıt "karaçam ağacı" (EDPT: 449; DTS: 569) $\rightarrow$ Kzk. tıt "karaçam" (Shnitnikov, 1966: 207).

Sözcük, Eski Uygurca metinlerinden TT I'de tıt "karaçam, çam ağacı" (Clauson, 1972: 449; Wilkens, 2021: 716), DLT'de tıt “çam ağacı" (Kaçalin, 2019: 471; Hauenschild, 1994: 75) şeklinde görülmektedir.

tiken "diken" (EDPT: 483; DTS: 558) $\rightarrow$ Kzk. tiken "diken" (Koç, 2003: 572).

Sözcük, Eski Uygurcada tiken "diken” (Rachmati, 1932: 5), DLT ve KB'de tiken “diken” (Kaçalin, 2019: 472; Arat, 1979: 445) şeklinde görülmektedir. Sözcük, Kıpçak Türkçesi eserlerinden TZ'de tiken "diken" (Atalay, 1945: 258), Çağatay Türkçesi eserlerinden MK'de tiken “diken” (Ölmez, 1993: 554) şeklinde görülmektedir.

tikenek "diken" (EDPT: 483) $\rightarrow$ tikenek "diken" (Koç, 2003: 573). 
Sözcük, Kıpçak Türkçesi eserlerinden Kİ ve TZ'de tikenek “diken” şeklinde görülmektedir (Atalay, 1945: 258; Caferoğlu, 1931: 102).

ur "tohum" (Toparl1, 2014: 293) $\rightarrow$ Kzk. urlık (ur + liḳ) "tohumluk, bitki tohumu; tane, tahıl” (KTAS: 700). Sözcük, Kazakçada yapım ekli şekilde görülmektedir.

Sözcük, yalnızca Kıpçak Türkçesi eserlerinden Kİde ur “tohum” şeklinde görülmektedir (Caferoğlu, 1931: 112).

urug "tohum" (EDPT: 214; DTS: 615) $\rightarrow$ Kzk. urlk" "tohum, bitki tohumu; tahıl, tane" (Koç, 2003: 587; Iskakov XIV, 2011: 744).

Sözcük Eski Uygurcada urug “tohum” (Rachmati, 1932: 3), DLT ve KB'de urug "tohum, tane" (Kaçalin, 2019: 523; Arat, 1979: 497) şeklinde görülmektedir. Sözcük, Harezm Türkçesi eserlerinden KE'de urug “tohum” (Ata, 1997: 672), Kıpçak Türkçesi eserlerinden BV'de uruk "bir bitki" (Ağar, 1986: 328), Çağatay Türkçesi sözlüklerinden LÇT'de urug / uruk "tohum; zerdali, kayısı" (Şeyh Süleymān Efendi, 1298: 31) şeklinde görülmektedir.

üzüm “üzüm” (EDPT: 288; DTS: 631; Eren, 1999: 431) $\rightarrow$ Kzk. üzim, jüzim “üzüm” (Koç, 2003: 189).

Sözcük, Eski Uygurcada üzüm “üzüm” (Rachmati, 1932: 83; Wilkens, 2021: 834), DLT'de üzüm “üzüm” (Kaçalin, 2019: 541; Hauenschild, 1994: 80) şeklinde görülmektedir. Ayrıca sözcük, Harezm Türkçesi eserlerinden ML'de üzüm “üzüm” (Battal, 1934: 83), Kıpçak Türkçesi eserlerinden GT ve Kİ'de üzüm “üzüm”, CC ve TZ'de yüzüm “üzüm” (Karamanlığlu, 1978: 386; Caferoğlu, 1931: 116; Grønbech, 1942: 132; Atalay, 1945: 291), Çağatay Türkçesi eserlerinden MK'de üzüm “üzüm” (Ölmez, 1993: 563) şeklinde görülmektedir. 
yabçan, yavçan “(bitki) pelin” (EDPT: 872; DTS: 235; Eren, 1999: $444) \rightarrow$ Kzk. juvsan “(bitki) pelin, ak pelin” (Koç, 2003: 184).

Sözcük, DLT'de yapçan / yavşan "yavşan otu” şeklinde görülmektedir (Kaçalin, 2019: 557; Hauenschild, 1994: 81). Sözcük, Kıpçak Türkçesi eserlerinden İH'de yavşan "bir tür ot, yavşan otu" (İzbudak, 1936: 51), Çağatay Türkçesi sözlüklerinden LÇT'de yavşan “yavşan otu” (Şeyh Süleymān Efendi, 1298: 301) şeklinde görülmektedir.

yagak “ceviz" (EDPT: 900; DTS: 224) $\rightarrow$ Kzk. jayak, jayg்k "ceviz" (Koç, 2003: 161).

Sözcük, Eski Uygurca metinlerinden Irk Bitig'de yagak “ceviz” (Tekin, 2013: 65), DLT'de yaġak “ceviz” (Kaçalin, 2019: 544; Hauenschild, 1994: 81) şeklinde görülmektedir. Çağatay Türkçesi sözlüklerinden LÇT'de yayag, yaykag “ceviz” (Şeyh Süleymān Efendi, 1298: 300) şeklinde görülmektedir.

yandak "deve dikeni, geven dikeni" (EDPT: 947; DTS: 232) $\rightarrow$

Kzk. jantak "10-15 cm'e kadar uzayan dikenli bir bitki; deve dikeni” (Koç, 2003: 161).

Sözcük, DLT'de yandak tiken "geven dikeni” şeklinde görülmektedir (Kaçalin, 2019: 554; Hauenschild, 1994: 82). Ayrıca sözcük, Harezm Türkçesi eserlerinden KE'de yandak “deve dikeni” şeklinde görülmektedir (Ata, 1997: 704).

yapurgak "yaprak" (EDPT: 879; DTS: 237) $\rightarrow$ Kzk. japırak, jarpak" "yaprak" (Koç, 2003: 162).

Sözcük, Eski Uygur metinlerinden U II yapırgak "yaprak" (Wilkens, 2021: 865), DLT'de yapurgak “yaprak" (Kaçalin, 2019: 558) şeklinde görülmektedir. Sözcük, Harezm Türkçesi eserlerinden NF'de yapurgak / yaprak “yaprak”, KE'de yafrak / yapurgak "yaprak" (Ata, 1997: 541; Ata, 1998: 498), Kıpçak Türkçesi eserlerinden Kİ ve TZ'de yaprak "yaprak" (Caferoğlu, 
1931: 119; Atalay, 1945: 279), Çağatay Türkçesi sözlüklerinden LÇT'de yaprak "yaprak" (Şeyh Süleymān Efendi, 1298: 289) şeklinde görülmektedir.

yarma "yarma, bulgur" (EDPT: 969) $\rightarrow$ Kzk. jarma, jarmak "yarma, yarmak, yarılmış buğday, arpa, darı" (Koç, 2003: 164; Iskakov VI, 2011: 105).

Sözcük, Kıpçak Türkçesi eserlerinden TZ'de yarma “yarma, bulgur” şeklinde geçmektedir (Atalay, 1945: 280).

yarpuz "güzel koku yayan bir bitki, nane" (EDPT: 957; DTS: 243) $\rightarrow$ Kzk. jalbız "nane" (Koç, 2003: 156). Sözcük çağdaş lehçelerden Kırgızcada calbı "nane" şeklinde görülmektedir (Yudahin, 2011: 167).

Sözcük, DLT'de yarpuz "güzel kokulu bir ot, kır nanesi" şeklinde görülmektedir (Kaçalin, 2019: 565; Hauenschild, 1994: 84). Ayrıca sözcük, Kıpçak Türkçesi eserlerinden İH'de yarpuz "yaban pancarı", TZ'de yarpuz "su nanesi" (İzbudak, 1936: 51; Atalay, 1945: 280), Çağatay Türkçesi sözlüklerinden LÇT’de yarpuz "kekik gibi bir ot" (Şeyh Süleymān Efendi, 1298: 291) şeklinde görülmektedir.

yasımuk, yasmuk "mercimek" (EDPT: 975; DTS: 245) $\rightarrow$ Kzk. jasımık "mercimek" (Koç, 2003: 167).

Sözcük, Eski Uygurca metinlerinde yasımuk "mercimek" şeklinde görülmektedir (Rachmati, 1932: 119). Sözcük, Harezm Türkçesi eserlerinden NF ve KE'de yasmuk "mercimek" (Ata, 1997: 714; Ata, 1998: 474), Kıpçak Türkçesi eserlerinden BM'de yasmık "yabani za'feran” (Zająckowski, 1954: 63), Çağatay Türkçesi sözlüklerinden LÇT'de yasmuk "mercimek" (Şeyh Süleymān Efendi, 1298: 294) şeklinde görülmektedir.

yava "yabani soğan" (EDPT: 871; DTS: 248) $\rightarrow$ Kzk. juva "yabani soğan" (Koç, 2003: 184). 
Sözcük Eski Uygurca TT V'de yava "yabani soğan" (Clauson, 1972: 871; Wilkens, 2021: 877), DLT'de yava "kolgan dikeni” (Kaçalin, 2019: 570; Hauenschild, 1994: 85) şeklinde görülmektedir. Ayrıca sözcük, Kıpçak Türkçesi eserlerinden TA'de yava "soğan", TZ'de yava "pırasa" şeklinde görülmektedir (Toparl1, 2000: 144; Atalay, 1945: 281).

yėmiş "meyve, yemiş" (EDPT: 938; DTS: 255; Eren, 1999. 451) $\rightarrow$ Kzk. jemis "meyve, yemiş” (Koç, 2003: 174).

Sözcük, Eski Uygurca metinlerden U II'de yemiş "yemiş, meyve" (Clauson, 1972: 938; Wilkens, 2021: 888), DLT'de yemiş "meyve" (Kaçalin, 2019: 583) şeklinde görülmektedir. Ayrıca sözcük, Harezm Türkçesi eserlerinden KE'de yemiş "meyve" (Ata, 1997: 724), Kıpçak Türkçesi eserlerinden CC ve TZ'de yemiş "yemiş, meyve" (Grønbech, 1942: 121; Atalay, 1945: 284), Çağatay Türkçesi sözlüklerinden LÇT'de yimiş "meyve, yemiş" (Şeyh Süleymān Efendi, 1298: 314) şeklinde görülmektedir.

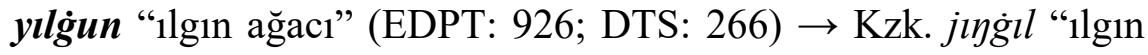
ağacı” (Koç, 2003: 193).

Sözcük, DLT'de yılg̀un “1lgın ağacı” şeklinde görülmektedir (Kaçalin, 2019: 591). Sözcük, Harezm Türkçesi eserlerinden ML'de $ı$ lg̀ın “1lgın” (Battal, 1934: 35), Kıpçak Türkçesi eserlerinden TA'de yllg̀un "1lgın ağacı" (Toparlı, 2000: 161) şeklinde görülmektedir.

yigde "iğde, iğde ağacı" (EDPT: 911; DTS: 260) $\rightarrow$ Kzk. jiyde "iğde" (Koç, 2003: 177).

Sözcük, Eski Uygurca metinlerde yigde "iğde" (Rachmati, 1932: 128), DLT'de yigde “iğde" (Kaçalin, 2019: 594) şeklinde görülmektedir. Sözcük, Harezm Türkçesi eserlerinden ML'de yigde “iğde, iğde ağacı” (Battal, 1934: 89), Kıpçak Türkçesi eserlerinden TA'de yigde “iğde” (Toparl1, 2000: 170), Çağatay Türkçesi 
eserlerinden LD’de yigde "iğde" (Karaağaç, 1997: 498) şeklinde görülmektedir.

yiken "karg1, kamış; hasır otu" (EDPT: 913) $\rightarrow$ Kzk. jeken "karg1, kamış" (Iskakov VI, 2011: 271).

Sözcük, DLT'de yigen "papürüs otu” şeklinde görülmektedir (Kaçalin, 2019: 594; Hauenschild, 1994: 87). Ayrıca sözcük, Kıpçak Türkçesi eserlerinden TZ'de yeken "karg1, kamış" şeklinde görülmektedir (Atalay, 1945: 283).

yonçga “yonca otu" (EDPT: 971; Eren, 1999: 457) $\rightarrow$ Kzk. jonışka, jonırışka "yonca” (Koç, 2011: 181).

Sözcük Eski Uygurcada yorı̧çğa "yonca" (Wilkens, 2021: 914), DLT'de yorınçg்a “yonca" (Kaçalin, 2019: 601; Hauenschild, 1994: 89) şeklinde görülmektedir. Sözcük, Harezm Türkçesi eserlerinden ML'de yonçğa “yonca” (Battal, 1934: 92), Kıpçak Türkçesi eserlerinden İH'de yonça "yonca" (İzbudak, 1936: 54), Çağatay Türkçesi sözlüklerinden LÇT'de yorunçğa "yonca" (Şeyh Süleymān Efendi, 1298: 305) şeklinde görülmektedir.

Sonuç: Kazakçanın söz varlığında; Köktürkçe, Eski Uygurca, Kutadgu Bilig, Divan-1 Lūgati’t-Türk, Kıpçakça ve Çağataycada bulunan birçok sözcügün korunduğu bilinen bir gerçektir. Bugünkü Kazakçanın söz varlığında Eski Türkçenin izini sürdüğümüz bu çalışmada verdiğimiz bitki adları da bu bilgiyi pekiştirmektedir. Çalışmamızda yer alan bitki adlarının çoğu Türkçe kökenli sözcüklerden oluşmakla birlikte bazı alıntı sözcükler de yer almaktadır. Örneğin; Eski Türkçe metinlerde görülen mirç, murç sözcügü, Sanskritçe marica, marīca (biber, karabiber) sözcüğünden alıntıdır. Sözcük Türkçenin tarihî dönemlerinden Kazakçaya kadar kullanılagelmiştir. Yine, Eski Türkçede görülen aluç (yaban eriği; şeftali) sözcüğü Farsça allūça sözcüğünden gelmektedir. Türkçenin tarihî dönemlerinden Kazakçaya gelene kadar alşa şekline bürünmüştür. $\mathrm{Bu}$ alıntı sözcüklere baktığımızda, Türkçenin tarihî 
dönemlerinde Türkçenin fonetik yapısına uydurularak alıntılandığ 1 ve buradan da Kazakçanın söz varlığına geçtiği görülmektedir.

Bitki adları genellikle Eski Türkçeden Kazakçaya gelene kadar anlam ve şekil açısından büyük ölçüde kendilerini korumuştur. Ancak bazı sözcüklerin Türkçenin farklı dönemlerinde çeşitli anlamlar ve şekillere bürünerek Kazakçaya geçtiğini görmekteyiz. Örneğin; Eski Türkçe metinlerde yapurğak "yaprak" şeklinde görülen sözcük Kıpçak ve Çağatay Türkçesi eserlerinde yaprak şeklinde görülmüş ve buradan da Kazakçaya aynı şekilde geçmiştir. Yine Eski Türkçe çaġmur/çamg்ur "şalgamlık turp" şeklinde görülen sözcük, Kazakçada şomır şeklinde görülmektedir. Bu durumun sebebi sözcüğün Türkçenin tarihi seyri içerisinde değişip yeni anlamlar kazanmasıdır. Bu kazandığı yeni anlam ve şekiller de Kazakçaya yansımıştır.

\section{Kisaltmalar}

BM: Bulgat al-Muštāq fìlugat at-Turkwa-l-Qifžāk $\rightarrow$ Zająckowski 1954.

BV: Baytaratü'l-Vâzıh $\rightarrow$ Ağar 1986.

CC: Komanisches Wörterbuch. Türkischer Wortindexzu Codex Cumanicus $\rightarrow$ Grønbech 1942.

DLT: Mahmûd el-Kâşgarî, Dîvânu Lugâti't-Turk $\rightarrow$ Kaçalin 2019.

DM: Ed-Dürretü'l-Mudiyye Fi'l-lügati't-Türkiyye $\rightarrow$ Toparl, 2003.

DTS: Drevnetyurskskiy slovar $\rightarrow$ Nadelyayev 1969.

EDPT: Etymological Dictionary of Pre-thirteenth Century Turkish $\rightarrow$ Clauson 1972 .

ESTY: Etimologiçeskiy Slovar Tyurkskih Yazıkov $\rightarrow$ Sevortyan 1974-2003.

ET: Eski Türkçe.

Far. : Farsça.

GT: Gülistan Tercümesi $\rightarrow$ Karamanlıoğlu 1978.

İM: Irşâdü'l-Mülukve's-Selâtîn $\rightarrow$ Toparl1 1992.

İH: El - İdrak Haşiyesi $\rightarrow$ İzbudak 1936.

KB: Kutadgu BiligIII (Index) $\rightarrow$ Arat 1979. 
KE: Kușașü'l-Enbiyā II (Dizin) $\rightarrow$ Ata 1997.

Kİ: Kitābu'l-İdrāk li Lisāni'l-Etrāk $\rightarrow$ Caferoğlu 1931.

KK: El-Kavânînü'l-Külliye Li-Zabti'l-Lügati't-Türkiyye $\rightarrow 1999$.

KTAS: Kazak Tilini门 Aymaktık Sözdigi $\rightarrow$ Kaliyev 2005.

Kzk. Kazakça.

LÇT: Şeyh Süleymān Efendi, Lugat-i Çă̆atay ve Türki-yi Osmani $\rightarrow$ Şeyh Süleymān Efendi 1298 .

LD: Mevlânâ Lutfî Dîvanı $\rightarrow 1997$.

Man III: Türkische Manichaicaaus Chostscho III $\rightarrow$ Le Coq 1922.

ME: Mukaddimetü'l-Edeb, Hvārizm Türkçesi ile Tercümeli Şuşter Nüshası (Giriş- Dil Özellikleri- Metin- Indeks) $\rightarrow 1993$.

MK: Mahbûbu'l-kulûb $\rightarrow$ Ölmez 1993.

ML: İbni-Mühennâ Lugati $\rightarrow$ Battal 1934.

NF: Nehcü'l-Feradis (Dizin) $\rightarrow$ Ata 1998.

Sans.: Sanskritçe.

ŞHD: Şîbân Han Dîvânı $\rightarrow$ Karasoy 1998.

TA: Kitâb-ı Mecmu-ı Tercümân-ı Türkî ve Acemî ve Mugalî $\rightarrow$ Toparli 2000.

TT I: Türkische Turfan-Texte $I \rightarrow$ Bang 1929.

TT V: Türkische Turfan-Texte $V \rightarrow$ Bang 1931.

TT VIII: Türkische Turfan-Texte VIII $\rightarrow$ Gabain 1954.

U III: Uigurica III $\rightarrow$ Müller 1920.

VEWT: Versuch eines etymologischen Wörterbuchs der Türksprachen $\rightarrow$ Räsänen 1969.

TZ: Ettuhfet-üz-Zekiyye Fil-Lugat'it-Türkiyye $\rightarrow$ Atalay 1945.

\section{Kaynaklar}

Abik, Ayşehan Deniz, 1993: Ali Şîr Nevâyı̂’nin Risâleleri Târîh-i Enbiyâ ve Hükemâ, Târîh-i Mülûk-i Acem, Münşeât: MetinGramatikal-Indeks-Sözlük. Ankara Üniversitesi Dil ve TarihCoğrafya Fakültesi Yayımlamamış Doktora Tezi.

Ağar, Mehmet Emin, 1986: Baytaratü'l-Vâzıh (Inceleme-Metinindeks). Yüksek Lisans Tezi. Marmara Üniversitesi Sosyal Bilimler Enstitüsü. 
Arat, Reşit Rahmeti, 1979: Kutadgu Bilig III. yay. Kemal Eraslan, Osman F. Sertkaya, Nuri Yüce. İstanbul: TKAE.

Atalay, Besim, 1945: Ettuhfet-üz-Zekiyye Fil-Lugat'it-Türkiyye. Ankara: Türk Dil Kurumu. , 1970: Abuşka Lûgati veya Çă̆atay Sözlüğü. Ankara: Ayy1ld1z. , 2013: Divanü Lugat-it Türk Tercümesi. Ankara: Türk Dil Kurumu.

Ata, Aysu, 1997: Kııșaṣü'l-Enbiyā II (Dizin). Ankara: Türk Dil Kurumu. , 1998: Nehcü'l-Feradis (Dizin). Ankara: Türk Dil Kurumu.

Bang, W., A. V. Gabain, 1929: Türkische Turfan-Texte I. Berlin. , 1931: Türkische Turfan-Texte V. Berlin.

Battal, Aptullah, 1934: İbni-Mühennâ Lugati. İstanbul: İstanbul Devlet Matbaası.

Bayniyazov, A., J. Bayniyazova, 2007: Türikşe-Kazakşa Sözdik. Almat1.

Baytop, Turhan, 2015: Türkçe Bitki Adları Sözlüğü. Ankara: Türk Dil Kurumu.

Caferoğlu, Ahmet, 1931: Abûu Hayyân Kitâb al-İdrâk li-lisân alAtrâk. İstanbul: Evkaf.

Clauson, Sir Gerard, 1972: An Etymological Dictionary of Prethirteenth Century Turkish. Oxford: Clarendon Press.

Dankoff, Robert (with James Kelly), 1982-1985: Maḥmūd alKāš Yarī, Compendium of the Turkic Dialects (DīwānLugāt atTurk) I-III. Cambridge: Harvard University Press. 
Eren, Hasan, 1999: Türk Dilinin Etimolojik Sözlüğü, Ankara: Bizim Büro Basımevi.

Gabain, A. V., 1954: Türkische Turfan-Texte VIII, Texte in Brāhmıschrift. Berlin.

Grønbech, Kaare, 1942: Komanisches Wörterbuch. Türkischer Wortindex zu Codex Cumanicus. Kopenhagen.

Hacreminoğlu, Necmettin, 2000: Kutb’un Husrev ü Şirin'i ve Dil Hususiyetleri. Ankara: Türk Dil Kurumu.

Hauenschild, Ingeborg, 1994: Botanica im Dīvān luġàt at-turk, Journal of Turkology, vol.2, no. 1, Summer, p. 25-100.

Iskakov, A., 1966: Kazak Tiliniך Kıskaşa Etimologiyalık Sözdigi. Almatı: Kazak SSR Ġ1lım.

Iskakov, A., 1974-1976: Kazak Tiliniๆ Tüsindirme Sözdigi 2 cilt Almatı: Kazak SSR Ġılım. , 1978-1986: Kazak Tiliniך Tüsindirme Sözdigi 10 cilt Almatı: Kazak SSR G1lım. , 2011: Kazak Ëdebi Tilinị Sözdigi 15 cilt. Almat1.

İzbudak, Velet, 1936: El - İdrak Haşiyesi. Ankara: Türk Dil Kurumu.

Kaçalin, Mustafa, 2019: Mahmûd el-Kâşgarî, Dîvânu Lugâti't-Turk (Yayına Hazırlayan: Mehmet Ölmez), İstanbul: Kabalc1.

Kaliyev, G., O. Hakısbekov, Ş. Sarıbayev, A. Uderbayev, 2005: Kazak Tilini门 Aymaktık Sözdigi. Almatı: Arıs.

Karaağaç, Günay, 1997: Mevlânâ Lutfî Dîvanı. Ankara: Türk Dil Kurumu.

Karamanlığlu, Ali Fehmi, 1978: Gülistan Tercümesi (Kitâb Gülistan bi’t Türkî). Ankara: Türk Dil Kurumu. 
Karasoy, Yakup, 1998: Şîbân Han Dîvânı (İnceleme-Metin-DizinTipkıbasım). Ankara: Türk Dil Kurumu.

Koç, Kenan, Ayabek Bayniyazov, Vehbi Başkapan, 2003: Kazak Türkçesi Türkiye Türkçesi Sözlüğü. Ankara: Akçağ.

Le Coq, Albert von, 1922: Türkische Manichaica aus Chostscho III. Nebsteinem-christlichen Bruchstückaus Bulayıq. Berlin: (APAW. Phil.-hist. K1. 1922).

Müller, F. W. K., 1920: Uigurica III. Berlin: APAW.

Nadelyayev, V. M., D. M. Nasilov, E. R. Tenişev, A. M. Şçerbak, 1969: Drevnetyurskskiy slovar'. Leningrad.

Oba, Emin, 2020: Kazakçanın Tarihî Türk Lehçelerine Göre Söz Varlı̆̆g. IQ Kültür-Sanat. , 2021: Қазақ Тілінің Тарихи Түркі Тілдері Тұрвысынан Сөздік Коры (Түсіндірме Сөздік). Almat1: Al-Farabi Üniversitesi Basımevi.

Öner, Mustafa, 2013: Bugünkü Kıpçak Türkçesi. Ankara: Türk Dil Kurumu.

Ölmez, Zuhal, 1993: Mahbûbu'l-kulûb, Inceleme-Metin-Sözlük. Doktora Tezi Hacettepe Üniversitesi Sosyal Bilimler Enstitüsü. 1996: Ebulgazi Bahadır Han Şecere-i Terākime (Türkmenlerin Soykütüğ̈̈). Ankara: Simurg.

Pavet de Corturteille, M., 1870: Dictionnarie Turk-Oriental. Paris. Rachmati, G. R., 1930: Zur Heilkunde der Uiguren I. SPAW. , 1932: Zur Heilkunde der Uiguren II. SPAW.

Räsänen, M., 1969: Versuch eines etymologischen Wörterbuchs der Türksprachen. Helsinki: Suomalais-Ugrilainen Seura. 
Röhrborn, Klaus, 1977-1996: Uigurisches Wörterbuch. Sprachmaterial der vorislamischen türkischen Texte aus Zentralasien: a - äryäk 1-6. Wiesbaden. , 2010: Uigurisches Wörterbuch. Sprachmaterial der vorislamischen türkischen Texte aus Zentralasien: I. Verben, Band 1: ab- äzüglä-. Stutgart: Neubearbeitung. , 2015: Uigurisches Wörterbuch. Sprachmaterial der vorislamischen türkischen Texte aus Zentralasien Neubearbeitung-: II. Nomina-Pronomina-Partikeln Band 1: a asvık. Stutgart: Neubearbeitung.

Sevortyan, Yervand Vladimiroviç, 1974-2003: Etimologiçeskiy Slovar Tyurkskih Yazıkov. Moskva.

Shnitnikov, Boris N., 1966: Kazakh-English Dictionary. London.

Steingass, Francis Joseph. 1892: Comprehensive Persian-English Dictionary, including the Arabicwords and phrasesto be met with in Persian literature. London.

Şeyh Süleymān Efendi, 1298: Lugat-i Çă̆atay ve Türki-yi Osmani. Tekin, Talat, 2017: Orhon Yazıtları. Ankara: BilgeSu.

Tietze, Andreas, 2002: Tarihî ve Etimolojik Türkiye Türkçesi Lugatı. Sprachgeschictliches und Etymologisches Wörterbuchdes Türkei-Türkischen I A-E. İstanbul-Wien: Simurg. , 2009: Tarihî ve Etimolojik Türkiye Türkçesi Lugati Sprachgeschictliches und Etymologisches Wörterbuchdes Türkei-Türkischen Cilt 2 F-J. Wien.

Toparl1, Recep, 1992: İşâdü'l-Müluk ve's-Selâtîn. Ankara: Türk Dil Kurumu. 
, 2003: Ed-Dürretü'l-Mudiyye Fi'l-lügati't-Türkiyye.

Ankara: Türk Dil Kurumu.

Toparl1, Recep, M. Sadi Çögenli, Nevzat H. Yanık, 1999: ElKavânînü'l-Külliye Li-Zabti'l-Lügati't-Türkiyye. Ankara: Türk Dil Kurumu. , 2000: Kitâb-ı Mecmu-ı Tercümân-ı Türkî ve Acemî ve Mugalî. Ankara: Türk Dil Kurumu.

Toparlı, Recep, Mustafa Argunşah, 2014: İslâm Mu'înü'l-Mürîd. Ankara: Türk Dil Kurumu.

Toparlı, Recep, Hanifi Vural, Recep Karaatlı, 2014: Kıpçak Türkçesi Sözlüğü. Ankara: Türk Dil Kurumu.

Wilkens, Jens, 2021: Handwörterbuch des Altuigurischen, Altuigurisch - Deutsch - Türkisch (Eski Uygurcanın El Sözlüğü, Eski Uygurca - Almanca - Türkçe). Göttingen: Universitetsverlag Göttingen.

Y1ldırım, Talip, 2010: Hüseyin Baykara Divanı: Metin-İncelemeDizin. İstanbul: Hat.

Yüce, Nuri, 1993: Mukaddimetü'l-Edeb, Hvārizm Türkçesi ile Tercümeli Şuşter Nüshası (Giriş- Dil Özellikleri- MetinIndeks). Ankara: Türk Dil Kurumu.

Yücel, Bilal, 1995: Bâbür Dîvânı (Gramer-Metin-SözlükTipkıbasım). Ankara: Atatürk Kültür Merkezi.

Yudahin, K. K., 2011: Kırgız Sözlüğ̈̈, çev. Abdullah Taymas. Ankara: Türk Dil Kurumu.

Zająckowski, Ananiansz, 1954: Bulgat al-Muštāq fì lug்at atTurkwa-l-Qifžāk. Warzawa. 